\title{
EVOLUTION OF AUSTRALIAN ISOLATES OF METHICILLIN-RESISTANT STAPHYLOCOCCUS AUREUS: A PROBLEM OF PLASMID INCOMPATIBILITY?
}

\author{
D. E. Townsend, N. Ashdown AND W. B. GRUBB* \\ School of Medical Technology, Western Australian Institute of Technology, Kent Street, \\ Bentley, Western Australia 6102
}

\begin{abstract}
Summary. Methicillin-resistant Staphylococcus aureus (MRSA), currently causing problems in Australian hospitals, have chromosomal penicillinase and carry a new family of incompatibility group I (IncI) plasmids that encode resistance to nucleic acid-binding compounds (NAB). These plasmids may carry additional determinants for penicillinase production and resistance to gentamicin and trimethoprim. By comparison, earlier MRSA isolates from Australia were NAB-sensitive and the penicillinase determinants were carried on IncI plasmids. The possibility that these newer MRSA isolates have the same 'clonal' origin as other MRSA isolates has been investigated. Forcible maintenance of IncI penicillinase plasmids and NAC-resistance plasmids in the same cells resulted in various recombination events. Similar recombination events to those generated in the laboratory have been found in MRSA isolates.
\end{abstract}

\section{INTRODUCTION}

It has been suggested that methicillin-resistant Staphylococcus aureus (MRSA) have arisen from a single clone (Lacey, 1972; Lacey and Grinsted, 1973). This hypothesis was based on the fact that MRSA characteristically have heterogeneous resistance to methicillin, orange pigmentation, similar survival rates on glass, high-level chromosomal resistance to streptomycin $(\mathrm{Sm})$ and two plasmids - a stable plasmid of mol. wt $2.9 \times 10^{6}$ coding for tetracycline $(\mathrm{Tc})$ resistance and a larger plasmid coding for penicillinase (pase) production and heavy-metal $(\mathrm{Cd}$ and $\mathrm{Hg}$ ) resistance. MRSA strains which differed from the original clone could be explained on the basis of mutation or the loss or acquisition of plasmids (Lacey and Grinsted, 1973).

There has been an epidemic spread of MRSA in Australian hospitals (Pavillard et al., 1982) leading to the suggestion that these strains are different from other strains of MRSA (McDonald, 1982). Using several of the characteristics mentioned above, Gedney and Lacey (1982) analysed recent isolates of MRSA from Australia and concluded that they were closely related to MRSA strains from other countries and

Received 1 Aug. 1984; accepted 29 Oct. 1984.

* Reprint requests should be sent to Dr W. B. Grubb. 
thus were derived from the original clone. However, other studies, based principally on a genetic analysis, have shown that the Australian strains differ markedly in many respects. They have chromosomal determinants for pase, and resistance to $\mathrm{Cd}, \mathrm{Hg}$, $\mathrm{Tc}$, erythromycin (Em), and low levels of Sm (Grubb et al., 1983; Townsend et al., 1983b). In addition, characteristically they carry cryptic plasmids of mol. wt $(1 \cdot 0-1 \cdot 9) \times 10^{6}$, a plasmid of mol. wt $(2 \cdot 8-3.0) \times 10^{6}$ when resistant to chloramphenicol $(\mathrm{Cm})$ and a plasmid of mol. wt (14.6-22) $\times 10^{6}$ (Lyon et al., 1982; Grubb et al., 1983; Lyon et al., 1983; Townsend et al., 1983b, and c, and 1984c; Lyon et al., 1984). The (14.6-22) $\times 10^{6}$ mol. wt plasmids determine resistance to quaternary ammonium compounds (Townsend et al., 1983a and 1984a; Grubb et al., 1983), propamidine isethionate (Townsend et al., 1984b), ethidium bromide and a range of compounds (Emslie et al., 1985, and in press) which share a common property of being nucleic acid-binding compounds (NAB). Consequently, resistance to these agents will be referred to as NAB resistance. The NAB-resistance plasmids also carry one or more of the determinants for pase, gentamicin $(\mathrm{Gm})$ resistance or trimethoprim (Tp) resistance (Townsend et al., 1983a, $1984 a$ and $1984 b$ ).

There is also evidence which indicates that the MRSA strains currently being isolated in Australian hospitals have only emerged in recent years. Strains isolated from an Australian hospital before the present outbreak are genetically different from the recent isolates (Townsend et al., 1984c). However, they are similar to the strains studied by Lacey and Grinsted (1973) on the basis of which they established their concept of the clonal origin of MRSA strains. Consequently, if the recently isolated Australian strains of MRSA originated from the same 'clone' as other MRSA strains, they must have undergone considerable rearrangement in the location of their resistance genes.

In a survey of over 300 MRSA strains recently isolated from hospitals in Australia, no strains were found which simultaneously carried a pase and heavy-metal-resistance plasmid and a NAB-resistance plasmid (Grubb et al., 1983). These observations suggested that the NAB-resistance plasmids may belong to the same incompatibility (Inc) group as the pase and heavy-metal-resistance plasmids. If this is the case, the acquisition of a NAB-resistance plasmid by a MRSA of the type reported by Lacey and Grinsted (1973) would require the relocation of the resistance determinants on the pase and heavy-metal-resistance plasmid. This paper demonstrates that the NAB-resistance plasmids and the pase and heavy-metal-resistance plasmids belong to IncI and examines the consequences of forcing a strain to carry the two incompatible plasmids. These results are discussed in relation to the possible evolution of Australian MRSA strains from a single clone.

\section{MATERIALS AND METHODS}

Strains of S. aureus. See table I; Drs J. Pearman and D. I. Annear provided the strains of MRSA isolated from Royal Perth Hospital, Western Australia and Dr. Tay Leng, Department of Pathology, Singapore, supplied the MRSA strains from Singapore hospitals.

Media and reagents. Mueller-Hinton Agar (MHA), Brain-Heart Infusion Broth (BHIB) and Brain-Heart Infusion Agar (BHIA) were supplied by Gibco Diagnostics (Madison, Wisconsin, USA). BHIBC and BHIAC contained sodium citrate $5 \mathrm{~g} / \mathrm{L}$.

Antibacterial sensitivity testing. Propamidine isethionate $(\mathrm{Pi})$ was used to detect NAB-resistance (Townsend et al., 1984b). Sensitivity testing was performed either by multipoint replication (Annear and Grubb, 1972) or with impregnated 6-mm disks. Multipoint replication 
TABLE I

Strains of $S$. aureus

\begin{tabular}{|c|c|c|}
\hline Strain no. & Properties* and plasmid content & Reference \\
\hline $\begin{array}{l}\text { WG247 } \\
\text { WG248 }\end{array}$ & $\begin{array}{l}\text { RN27, phage } 80 \alpha \text { lysogen } \\
\text { RN450, plasmid free, non-lysogenic, sensitive to all } \\
\text { antibacterial agents used }\end{array}$ & $\begin{array}{l}\text { Novick, } 1963 \\
\text { Townsend et al., } \\
1983 b \text {; Novick \& } \\
\text { Bouanchaud. } 1971\end{array}$ \\
\hline WG541 & WG $248+$ chromosomal $\mathrm{Fa}^{\mathrm{R}}, \mathrm{Rf}^{\mathrm{R}}$ & Townsend et al., $1983 b$. \\
\hline WG822 & WG541, phage 95 lysogen & Townsend et al., $1983 b$. \\
\hline WG879 & WG541, phage 85 lysogen & Townsend et al., $1983 b$. \\
\hline WG1876 & WG541, phage J lysogen & Townsend et al., $1984 b$. \\
\hline WG516 & WG248+p1258 (pase $\mathrm{Cd}^{\mathrm{R}} \mathrm{Hg}^{\mathrm{R}} \mathrm{Asa}^{\mathrm{R}} \mathrm{Em}^{\mathrm{R}}$, mol. wt $18.4 \times 10^{6}$ ) & Novick et al., 1979 . \\
\hline WG2000 & 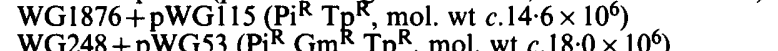 & Townsend et al., $1984 b$. \\
\hline $\begin{array}{l}\text { WG1320 } \\
\text { WG1348 }\end{array}$ & WG822+pWG51 ( $\mathrm{Pi}^{\mathrm{R}}$ pase Gm $\mathrm{Gm}^{\mathrm{R}}$, mol. wt $\left.c .19 .6 \times 10^{6}\right)$ & Townsend et al. $1984 a$. 1984 . \\
\hline WG1451 & WG822+pWG54 (Pi ${ }^{\mathrm{R}} \mathrm{Gm}^{\mathrm{R}}$, mol. wt $c .15 .3 \times 10^{6}$ & Townsend et al., $1984 a$. \\
\hline $\begin{array}{l}\text { WG881 } \\
\text { WG1433 }\end{array}$ & $\begin{array}{l}\text { WG879+pWG50 (pase } \mathrm{Cd}^{\mathrm{R}} \mathrm{Hg}^{\mathrm{R}} \mathrm{Gm}^{\mathrm{R}} \text {, mol. wt } c .28 .5 \times 10^{6} \text { ). } \\
\text { MRSA, isolated at Royal Perth Hospitai, } 1982 \text {, carries pWG } 405 \\
\text { (pase Cd } \mathrm{d}^{\mathrm{R}} \mathrm{Hg}^{\mathrm{R}} \text { Asa } \mathrm{R}^{\mathrm{R}} \text {, mol. wt } c .20 \times 10^{6} \text { ) }\end{array}$ & Townsend et al., $1983 b$. \\
\hline WG1547 & WG822+pWG405 (transferred by mixed culture from WG1433) & \\
\hline $\begin{array}{l}\text { WG1437- } \\
\text { WG1443 }\end{array}$ & $\begin{array}{l}\text { MRSA isolated at Royal Perth Hospital, } 1969-1973 \text {. Strain } \\
\text { WG1439 carries pWG404 (pase } \mathrm{Cd}^{\mathrm{R}} \mathrm{Hg}^{\mathrm{R}} \mathrm{Asa}^{\mathrm{R}} \text {, mol. wt } \\
c .20 \times 10^{6} \text { ) }\end{array}$ & \\
\hline WG1552 & $\begin{array}{l}\text { WG } 822+\text { pWG } 404 \text { (transferred by mixed culture from strain } \\
\text { WG1439) }\end{array}$ & \\
\hline WG939 & $\begin{array}{l}\text { Methicillin-sensitive isolate from Royal Perth Hospital, carries } \\
\left.\text { pWG80 (pase Cd }{ }^{R} \mathrm{Hg}^{\mathrm{R}} \text { Asa }^{\mathrm{R}} \text {, mol. wt } c .15 \cdot 1 \times 10^{6}\right)\end{array}$ & \\
\hline WG1119 & WG 248 + pWG 80 (transferred by phage 80 from strain WG939) & \\
\hline WG1983 & $\begin{array}{l}\text { MRSA, isolated in Singapore, carries pWG } 278\left(\mathrm{Pi}^{\mathrm{R}} \mathrm{Cd}^{\mathrm{R}} \mathrm{Hg}^{\mathrm{R}} \text {, }\right. \\
\left.\text { mol. wt } c .16 .9 \times 10^{6}\right)\end{array}$ & \\
\hline WG3192 & $\begin{array}{l}\text { WG } 1876+\text { pWG } 278 \text { (transferred by mixed culture from strain } \\
\text { WG1983) }\end{array}$ & \\
\hline WG1988 & $\begin{array}{l}\text { MRSA, isolated in Singapore, carries pWG202 }\left(\mathrm{Pi}^{\mathrm{R}} \text { pase } \mathrm{Cd}^{\mathrm{R}}\right. \\
\left.\mathrm{Hg}^{\mathrm{R}} \text {, mol. wt } c .19 .5 \times 10^{6}\right)\end{array}$ & \\
\hline WG2306 & $\begin{array}{l}\text { WG1 } 1876+\text { pWG202 (transferred by mixed culture from strain } \\
\text { WG1988) }\end{array}$ & \\
\hline WG1986 & $\begin{array}{l}\mathrm{MRSA} \text {, isolated in Singapore, carries pWG200 }\left(\mathrm{Pi}^{\mathrm{R}} \text { pase } \mathrm{Cd}^{\mathrm{R}}\right. \\
\left.\mathrm{Hg}^{\mathrm{R}} \text {, mol. wt } c .18 .4 \times 10^{6}\right)\end{array}$ & \\
\hline WG2312 & $\begin{array}{l}\text { WG1876+pWG200 (transferred by mixed culture from strain } \\
\text { WG1986). }\end{array}$ & \\
\hline
\end{tabular}

* $\mathrm{Rf}=$ rifampicin; $\mathrm{Fa}=$ fusidic acid $;$ pase $=$ penicillinase; Asa $=$ arsenate Em $=$ erythromycin; $\mathrm{Pi}=$ propamidine isethionate; $\mathrm{Tp}=$ trimethoprim; $\mathrm{Gm}=$ gentamicin; superscript $\mathrm{R}=$ resistance.

was on BHIA containing one of the following: Pi (May and Baker, Melbourne, Australia) 100

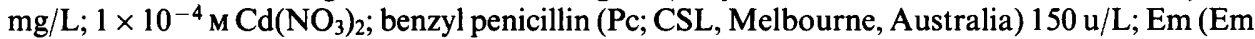
lactobionate, Abbott Laboratories, Kurnell, Australia) $2 \mathrm{mg} / \mathrm{L} ; \mathrm{Gm}$ (Schering Corp., Baulkam Hills, Australia) $2 \mathrm{mg} / \mathrm{L}$; or on MHA containing Tp (Wellcome Australia Ltd) $5 \mathrm{mg} / \mathrm{L}$. For disk sensitivity tests, MHA plates were flooded with an overnight broth culture diluted 100 -fold in physiological saline. The excess fluid was removed and disks were applied to the dried plates. The disks contained the following quantities of antibacterial reagents: $\mathrm{Pi}, 100 \mu \mathrm{g} ; \mathrm{Cd}, 0.2 \mu \mathrm{mol}$ of Cd $\left(\mathrm{NO}_{3}\right)_{2} ; \mathrm{Pc}, 1.5 \mathrm{u} ; \mathrm{Em}, 10 \mu \mathrm{g} ; \mathrm{Gm}, 10 \mu \mathrm{g} ; \mathrm{Tp}, 5 \mu \mathrm{g} ; \mathrm{Hg}, 0.4 \mu \mathrm{mol}$ of $\mathrm{HgCl}_{2} ;$ Asa, $0.2 \mu \mathrm{mol}$ of $\mathrm{NaHAsO}_{4}$. Strain WG248 was used as a sensitive control and strains WG1320 and WG516 as resistant controls.

Pase production was detected by the PNCB method (Novick and Richmond, 1965) or with Nitrocefin (Oxoid, Melbourne, Australia), a chromogenic cephalosporin.

Bacteriophage propagation. Bacteriophage $80 \alpha$, a derivative of international typing bacteriophage 80 (Novick, 1963), produces high-titre lysates on strain WG248. This phage was induced from strain WG 247 by ultra-violet (UV) irradiation followed by semi-solid propagation (Grubb 
and O'Reilly, 1971) at $30^{\circ} \mathrm{C}$ on strains WG248, WG516 and WG1119. All phage lysates were membrane-filtered, checked that they were free of viable bacteria and stored at $4^{\circ} \mathrm{C}$.

Transduction. Recipient organisms were grown on BHIA containing an antibacterial agent that would select cells containing a particular plasmid. The cells were harvested and $5 \times 10^{9}$ cells suspended in $9 \mathrm{ml}$ of BHIB containing $0.01 \mathrm{M} \mathrm{CaCl}_{2}$ at $37^{\circ} \mathrm{C}$. Phage $80 \alpha$ was added at a multiplicity of infection of $0.1-0.2$ and the mixture gently agitated for $35 \mathrm{~min}$ at $37^{\circ} \mathrm{C}$. $\mathrm{Ca}^{++}$was sequestered by the addition of $100 \mu \mathrm{l}$ of sterile sodium citrate $(500 \mathrm{~g} / \mathrm{L})$. The cells were washed twice with BHIBC and then resuspended in $1.0 \mathrm{ml}$ of BHIBC. After standing for $2 \mathrm{~h}$ at $37^{\circ} \mathrm{C}$, $100-200-\mu \mathrm{l}$ volumes were spread on to pre-dried plates which were either single-selection plates of BHIAC $+1 \times 10^{-4} \mathrm{M} \mathrm{Cd}$ or double-selection plates of BHIAC $+5 \times 10^{-5} \mathrm{M} \mathrm{Cd}$ and either $\mathrm{Gm} 2$ $\mathrm{mg} / \mathrm{L}$ or $\mathrm{Pi} 100 \mathrm{mg} / \mathrm{L}$. As a control, recipients without added phage were treated in the same manner. Transductants were purified on media of the same composition as used for their selection.

Mixed-culture transfer. One $\mathrm{ml}$ of an overnight culture of the recipient was placed in a petri dish which was slowly rotated while exposed for $30 \mathrm{~s}$. to a $15 \mathrm{~W}$ germicidal lamp at a distance of $450 \mathrm{~mm}$. Equal volumes $(50 \mu \mathrm{l})$ of the irradiated recipient and an overnight culture of the donor were added to $5.0 \mathrm{ml}$ of BHIB containing $0.01 \mathrm{M} \mathrm{CaCl}_{2}$. After gentle shaking for $18 \mathrm{~h}$ at $37^{\circ} \mathrm{C}$, the cultures were centrifuged and the pelleted cells were spread on to selective media and incubated for $48 \mathrm{~h}$ at $37^{\circ} \mathrm{C}$. Single colonies were purified on plates of the same composition as the selection plates. Separate donor and recipient cultures were always treated in parallel as controls. All transcipients were confirmed by comparing their antibiogram with that of the donor and recipient and by plasmid analysis.

When selecting for the transfer of an individual plasmid, single-selection plates were used, consisting of BHIA containing rifampicin (Rf; Lepetit, Milan, Italy) $50 \mathrm{mg} / \mathrm{L}$, fusidic acid (Fa; Leo Laboratories, Ballerup, Denmark) $5 \mathrm{mg} / \mathrm{L}$ and either Pi $200 \mathrm{mg} / \mathrm{L}$ or $1 \times 10^{-4} \mathrm{M} \mathrm{Cd}$. When a plasmid was being transferred into a strain with a resident plasmid, both plasmids were selected on double-selection plates containing $\mathrm{Rf} 25 \mathrm{mg} / \mathrm{L}, \mathrm{Fa} 5 \mathrm{mg} / \mathrm{L}$ and two of the following: $5 \times 10^{-5}$ M Cd, Pi $100 \mathrm{mg} / \mathrm{L}$, Em $5 \mathrm{mg} / \mathrm{L}, \mathrm{Pc} 150 \mathrm{u} / \mathrm{L}$ and $\mathrm{Gm} 2 \mathrm{mg} / \mathrm{L}$.

Plasmid stability. All plasmids were tested for their stability in the incubation conditions used for incompatibility testing. Cultures carrying a known plasmid were grown overnight in BHIB containing an appropriate selective agent for cells carrying the plasmid. Fifty $\mu$ l of overnight culture was transferred to $5.0 \mathrm{ml}$ of BHIB, incubated at $30^{\circ} \mathrm{C}$ or $37^{\circ} \mathrm{C}$ for $18 \mathrm{~h}$, plated out for single colonies and 100 colonies were replicated to $\mathrm{Cd}$ or Pi plates.

Segregation tests for plasmid incompatibility. Strains carrying plasmid pairs were established on the appropriate, double-selection plates. Five single colonies from each selection were purified on media of the same composition and a single colony from each plate was grown for 18 $\mathrm{h}$ in $5.0 \mathrm{ml}$ of BHIB at $37^{\circ} \mathrm{C}$ or $30^{\circ} \mathrm{C}$. Single colonies were obtained in BHIA at $37^{\circ} \mathrm{C}$ and 100 colonies were picked and replicated to BHIA and BHIA plates containing, separately, the antibacterial agents used to establish the plasmid pair. Any single colony that retained resistance to both agents was re-tested for segregation of the plasmid-borne resistance markers.

Plasmid pI258 was used as the reference plasmid for IncI (Novick and Richmond, 1965).

Plasmid loss at elevated temperature. A loopful of a broth culture was streaked on to a BHIA plate and incubated at $43 \cdot 5^{\circ} \mathrm{C}$ in a sealed chamber. After incubation for $18 \mathrm{~h}$, a sample of growth was plated on to BHIA for single colonies which were screened for resistance.

Plasmid DNA analysis. Methods for the isolation of plasmid DNA, analysis by agarose-gel electrophoresis and measurement of plasmid mol. wt were as described by Townsend et al. (1984b). Mol. wts were calculated by means of a computer programme (Duggleby et al., 1981).

The location of all the transferable resistance determinants was confirmed by plasmid analysis of donor and transcipient strains. If the donor carried a plasmid of identical mol. wt to that in the transcipient, the resistance determinants transferred were assigned to this plasmid.

RESULTS

Plasmid stability

The results are summarised in table II. 
TABLE II

Plasmid stability at $30^{\circ} \mathrm{C}$ and $37^{\circ} \mathrm{C}$

\begin{tabular}{|c|c|c|c|c|c|}
\hline \multirow{2}{*}{$\begin{array}{c}\text { Strain } \\
\text { no. }\end{array}$} & \multirow[b]{2}{*}{ Plasmid } & \multirow{2}{*}{$\begin{array}{c}\text { Plasmid } \\
\text { markers* }\end{array}$} & \multirow{2}{*}{$\begin{array}{l}\text { Resistance } \\
\text { screened }\end{array}$} & \multicolumn{2}{|c|}{$\begin{array}{l}\text { Percentage of colonies } \\
\text { resistant } \\
\text { after incubation at }\end{array}$} \\
\hline & & & & $30^{\circ} \mathrm{C}$ & $37^{\circ} \mathrm{C}$ \\
\hline WG2000 & pWG115 & $\mathrm{Pi}^{\mathrm{R}} \mathrm{Tp}^{\mathrm{R}}$ & $\mathrm{Pi}$ & 86 & 70 \\
\hline WG1320 & pWG53 & $\mathrm{Pi}^{\mathrm{R}^{\mathrm{R}}} \mathrm{Gm}_{\mathrm{T}}^{\mathrm{R}} \mathrm{Tp}^{\mathrm{R}}$ & $\mathrm{Pi}$ & 100 & 96 \\
\hline WG1348 & pWG51 & $\mathrm{Pi}^{\mathrm{R}} \mathrm{Gm}^{\mathrm{R}}$ pase & $\mathrm{Pi}$ & 96 & 93 \\
\hline WG1451 & pWG54 & $\mathrm{Pi}^{\mathrm{R}} \mathrm{Gm}^{\mathrm{R}}$ & $\mathrm{Pi}$ & 100 & 94 \\
\hline WG516 & p1258 & $\begin{array}{l}\text { pase } C^{R}{ }^{R} g^{R} \\
\text { Asa }{ }^{R} \operatorname{Em}^{R}\end{array}$ & $\mathrm{Cd}$ & 100 & 100 \\
\hline WG1119 & pWG80 & pase ${ }^{R} d^{R} H^{R}$ & $\mathrm{Cd}$ & 100 & 100 \\
\hline WG1547 & pWG405 & pase $_{\text {Asa }} \mathrm{Cd}^{\mathrm{R}} \mathrm{Hg}^{\mathrm{R}}$ & $\mathrm{Cd}$ & 100 & 100 \\
\hline WG1552 & pWG404 & ${ }_{\text {Asa }}{ }^{R} C^{R} H^{R}$ & $\mathrm{Cd}$ & 100 & 100 \\
\hline WG881 & pWG50 & $\mathrm{Gm}^{\mathrm{R}} \mathrm{Cd}^{\mathrm{R}} \mathrm{Hg}^{\mathrm{R}}$ & $\mathrm{Cd}$ & 100 & 100 \\
\hline
\end{tabular}

* See footnote to table I for abbreviations.

\section{Displacement of resident plasmid}

Strain WG1320 carries the resident plasmid, pWG53, and was harvested from Pi plates to ensure all recipient cells carried this plasmid. Plasmid pI258 was transduced from strain WG516 to strain WG1320 by a Cd selection. Fifty transductants were replicated and all were resistant to $\mathrm{Cd}$ but sensitive to $\mathrm{Pi}$.

Apparently, the resident plasmid, pWG53, was being displaced by the incoming plasmid, pI258, indicating that both may belong to the same incompatibility group (IncI). To confirm this, the segregation of the plasmids in the daughter cells was studied.

\section{Incompatibility grouping of plasmids determining resistance to $N A B$}

Mixed-culture transfer or transduction was used to transfer plasmid pI258 to strains carrying one of the representative, NAB-resistance plasmids-pWG53, pWG115, pWG51 or pWG54. To prevent displacement of the resident plasmid by the incoming plasmid during transfer, selection was made for both plasmids on double-selection plates. Strains carrying both plasmid markers were then tested for the segregation of these markers (table III).

Previous work with plasmids encoding resistance to NAB agents had demonstrated that they were unstable at elevated incubation temperatures (Townsend et al., 1983a and $b$, and $1984 b$ ). The results shown in table II suggest that they are more stable at $30^{\circ} \mathrm{C}$ than $37^{\circ} \mathrm{C}$. An emperical observation has also been made that more plasmid DNA can be detected in agarose gels when the cells carrying the NAB-resistance plasmids are grown at $30^{\circ} \mathrm{C}$ instead of $37^{\circ} \mathrm{C}$. This suggests that the copy number for these plasmids was higher at the lower temperature. In view of these observations, the 


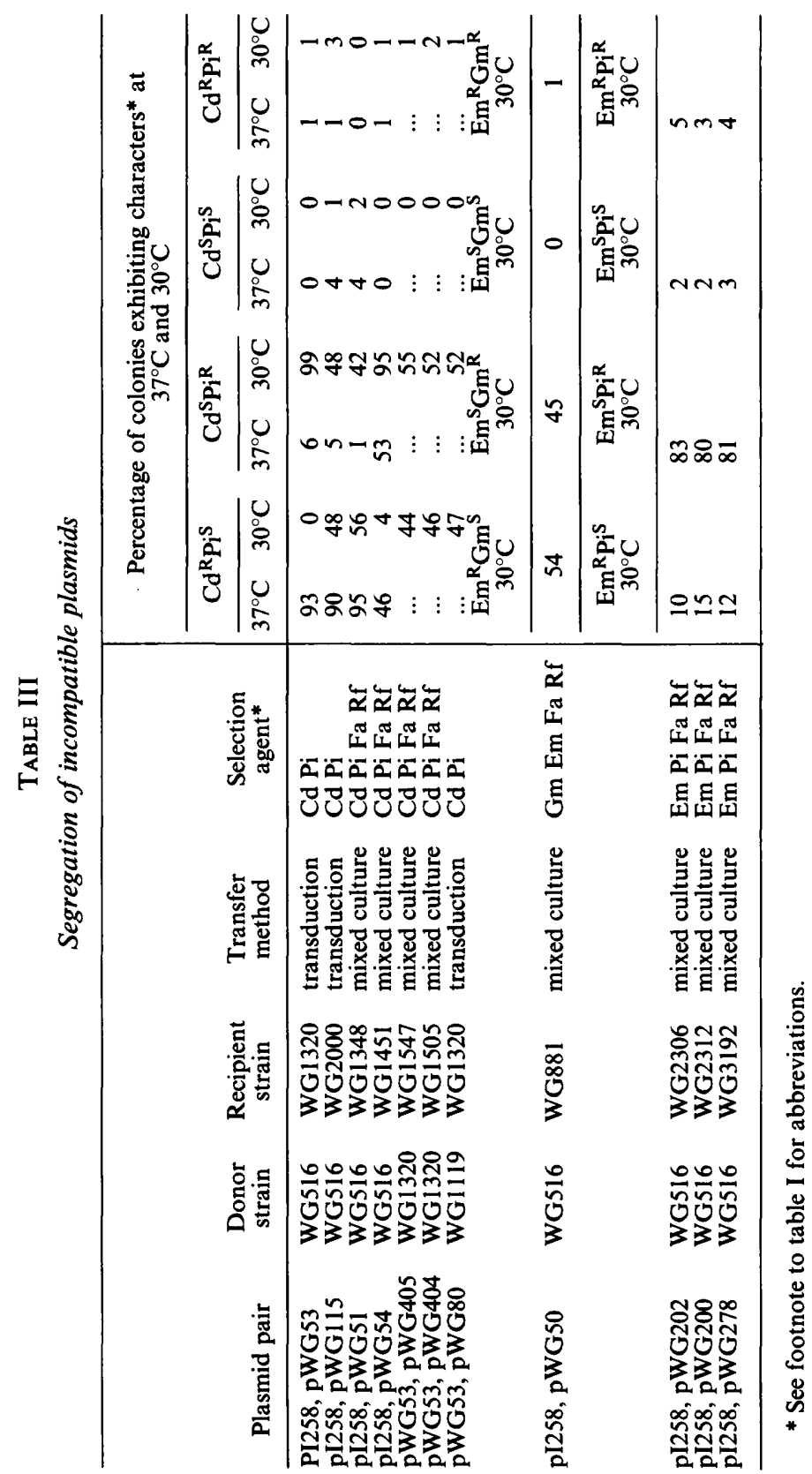


segregation tests were repeated at $30^{\circ} \mathrm{C}$ and all further tests were performed at this temperature (table III).

All colonies that retained both plasmid markers showed segregation on re-testing.

Incompatibility grouping of plasmids determining penicillinase production and heavymetal resistance

The above results established that the plasmids encoding resistance to NAB were IncI plasmids. Consequently, one of these plasmids, pWG53, was used to determine whether the pase plasmids in other isolates belonged to IncI.

MRSA strains WG1433 and WG1437-WG1443 all carried a plasmid of mol. wt $c$. $20 \times 10^{6}$ which transferred to WG822 in mixed culture with selection for Cd resistance. All plasmids coded for pase and resistance to $\mathrm{Cd}, \mathrm{Hg}$ and Asa. Representative plasmids, pWG404 and pWG405 (from strains WG1439 and WG1433, respectively), were tested for incompatibility with plasmid pWG53. The results are summarised in table III.

Isolate WG939 contained a plasmid, pWG80, of mol. wt $c .15 \cdot 1 \times 10^{6}$ which was representative of pase and heavy-metal-resistance plasmids in several strains of methicillin-sensitive $S$. aureus isolated from Royal Perth Hospital. When plasmid pWG80 was transduced to strain WG1320, segregation tests indicated that the two plasmids belonged to the same Inc group (table III). Plasmid pWG80 had the same phenotype and $E c o \mathrm{R} 1$ restriction fragments as pI6187 (unpublished results), which is a reference IncI plasmid isolated from several parts of the world (Shalita et al., 1980).

\section{Gene rearrangements.}

Usually, in the plasmid transfer experiments, when selection was made for two plasmids, both the selection and purification plates had mainly small colonies with the occasional $(<1 \%)$ large colony. It was reasoned that the small colonies resulted from the cells being forced to carry two incompatible plasmids, while in the cells of the large colonies, the plasmid genes had undergone rearrangement to produce a more stable configuration which would depend upon the selective pressure exerted and upon the original plasmid pairs. To confirm this, large colonies from different plasmid pairs and different double-selection media were picked and purified on media of the same composition. The colonies were tested for segregation of selection markers and screened by disk sensitivity tests for plasmid markers. Additionally, they were analysed for plasmid DNA. Representative examples of the results are presented in table IV. None of the large colonies showed subsequent segregation of resistance markers (results not shown).

When plasmids pWG53 and pWG80 were paired by transducing pWG80 into strain WG1320 and selection was made on $\mathrm{Gm}$ and Cd, a much higher proportion (up to $30 \%$ of larger colonies was observed. Five small colonies, tested for plasmid incompatibility, showed the same pattern of segregation for this plasmid pair as shown in table III. Of 20 large colonies examined, 19 were resistant to $\mathrm{Pc}, \mathrm{Cd}, \mathrm{Hg}, \mathrm{Asa}$ and $\mathrm{Gm}$ but sensitive to $\mathrm{Pi}$ and $\mathrm{Tp}$. All 19 showed co-loss of resistance to $\mathrm{Pc}$ and $\mathrm{Cd}$ after incubation at elevated temperature but no loss of $\mathrm{Gm}$ resistance. Plasmid analysis 
TABLE IV

Recombinants generated from pairing incompatible plasmids

\begin{tabular}{|c|c|c|c|c|c|c|}
\hline $\begin{array}{l}\text { Strain } \\
\text { no. }\end{array}$ & $\begin{array}{l}\text { Incoming } \\
\text { plasmid }\end{array}$ & $\begin{array}{l}\text { Resident } \\
\text { plasmid }\end{array}$ & $\begin{array}{c}\text { Double } \\
\text { selection agents* }\end{array}$ & Antibacterial-resistance profile* & $\begin{array}{l}\text { Number of } \\
\text { plasmids }\end{array}$ & $\begin{array}{l}\text { Plasmid mol. wt } \\
\left(\times 10^{6}\right)\end{array}$ \\
\hline WG2383 & pWG53 & pWG80 & Gm Pc & Gm Pc Cd Hg Asa & 1 & $c .17$ \\
\hline WG 2386 & 53 & NG80 & $\mathrm{PiCd}$ & $\mathrm{Pi} \mathrm{Gm} \mathrm{Tp} \mathrm{Pc} \mathrm{Cd} \mathrm{Hg} \mathrm{Asa}$ & i & \\
\hline WG2410 & $\begin{array}{l}\text { pWG53 } \\
\text { pWo }\end{array}$ & pWG80 & $\mathrm{Pi} \mathrm{Cd}$ & $\mathrm{Pi} \mathrm{Gm} \mathrm{Cd} \mathrm{Hg}$ & 1 & c. 30 \\
\hline WG 2422 & pWG53 & pWG80 & Pi Pc & Pi Gm Tp Pc Cd Hg Asa & 1 & $c .33$ \\
\hline WG2404 & $\begin{array}{ll}\text { p1258 } \\
\text { p }\end{array}$ & pWG51 & $\mathrm{Em} \mathrm{Pi}$ & Pc Cd Hg Em Pi Gm & 1 & $>35 \dagger$ \\
\hline WG2407 & pI 258 & pWG54 & $\mathbf{E m ~ P i}$ & $\mathrm{Em} \mathrm{Pi} \mathrm{Gm}$ & 1 & $c .17$ \\
\hline WG2468 & p1258 & pWG50 & $\mathrm{Em} \mathrm{Gm}$ & Pc Cd Hg Asa Em Gm & 1 & $>35 \dagger$ \\
\hline WG1357 & pWG80 & pWG53 & $\mathrm{Cd} \mathrm{Gm}$ & $\mathrm{Pc} \mathrm{Cd} \mathrm{Hg} \mathrm{Asa} \mathrm{Gm}$ & $i$ & $c .15$ \\
\hline WGI 359 & pWG80 & pWG53 & $\mathrm{Cd} \mathrm{Gm}$ & Pc Cd Hg Pi Gm Tp & $i$ & $c .33$ \\
\hline
\end{tabular}

* See footnote to table I for abbreviations.

t A more accurate estimate of the mol. wt has not been given because the mol. wts of the plasmids fall outside the limits of the standard curve (see Materials and Methods).

revealed a plasmid identical in mol. wt to plasmid pWG80. The results obtained with strain WG1357 are given, as an example, in table IV.

The one remaining large colony (from strain WG1359) was resistant to $\mathrm{Pc}, \mathrm{Cd}, \mathrm{Hg}$, $\mathrm{Gm}, \mathrm{Tp}$ and Pi but sensitive to Asa. Plasmid loss at elevated temperature was at a low frequency $(3 \%)$ and corresponded with co-loss of all the plasmid resistance markers. Plasmid analysis revealed a plasmid of mol. wt $c .33 \times 10^{6}$ (table IV).

\section{Naturally occurring recombinant plasmids.}

The results obtained with strain WG1359 indicated that one type of gene rearrangement within a strain carrying incompatible plasmids is recombination between the plasmids. Consequently, MRSA isolated from around the world were analysed for plasmids which could have arisen as the result of a similar recombination.

Of 16 MRSA strains received from Singapore hospitals, 13 were resistant to $\mathrm{Pi}$ and 11 transferred this resistance to strain WG1876 in mixed culture. Analysis of the transcipients from each MRSA revealed that nine produced pase and expressed resistance to $\mathrm{Pi}, \mathrm{Cd}$ and $\mathrm{Hg}$; seven of these carried a plasmid of mol. wt c.19.5 $10^{6}$, and the remaining two carried a plasmid of mol. wt $c .18 .4 \times 10^{6}$. The other two transcipients expressed resistance to $\mathrm{Pi}, \mathrm{Cd}$ and $\mathrm{Hg}$ and carried a plasmid of mol. wt c.16.9 $\times 10^{6}$. In each case, the plasmid in the transcipient was of the same mol. wt as the plasmid in the original MRSA (results not shown).

Plasmids pWG200, pWG202 and pWG278 were selected as representative of each plasmid type and tested for incompatibility with plasmid pI258, with Pi and Em as the selective markers for the plasmid pairs. All were shown to be IncI plasmids (table III).

Another plasmid, pWG50, from MRSA strain WG526, isolated at Royal Melbourne Hospital, Victoria, has previously been described as a recombinant plasmid (Townsend et al., 1984a). This conclusion was based on EcoRI restriction analysis and on its stability at an elevated incubation temperature. Incompatibility tests indicated that this plasmid also belongs to the IncI group (table III). 


\section{Discussion}

The results of the segregation tests (see table III) cannot be explained in terms of plasmid instability (see table II) but clearly establish plasmids pWG51, pWG53, pWG54 and pWG115 as IncI plasmids. These plasmids are representative of a family of NAB-resistance plasmids which have been found in MRSA strains recently isolated in Australia (Townsend et al., 1984a and $b$ ).

Staphylococcal plasmids have been classified into incompatibility groups and these contain plasmids of the same or similar phenotype. IncI plasmids are basically heavy-metal-resistance plasmids most of which carry a pase determinant and one, pI258, carries the Em-resistance determinant, Tn551 (Shalita et al., 1980). All the other staphyloccocal Inc groups contain plasmids with the same phenotype (Ruby and Novick, 1975; Iordanescu et al., 1978; Iordanescu and Surdeanu, 1980). The discovery of NAB-resistance plasmids belonging to IncI means that this is the first group of staphylococcal plasmids to be shown to contain plasmids with unrelated phenotypes. Moreover, plasmids pWG51, pWG53, pWG54 and pWG115 do not appear to be related to pase plasmids when examined in an EcoR1-restriction-enzyme analysis (Townsend et al., 1984a and $b$ ), a method which has previously been used to establish relatedness amongst IncI plasmids (Novick et al., 1979).

The segregation patterns of plasmids pWG51, pWG53, pWG54 and pWG115, when paired with plasmid pI258, differed considerably depending on the plasmid pair and the incubation temperature (table III). The results suggest that the effect of temperature may have been a reflection of the copy number of the plasmids. At $30^{\circ} \mathrm{C}$, Pi-resistance plasmids apparently have a higher copy number which favours their retention. This accords with a mathematical model proposed for segregation of incompatible plasmids by Novick and Hoppensteadt (1978).

Because Pi resistance is an easily selected and identifiable plasmid marker, plasmid pWG53 was used to classify pWG80, pWG404 and pWG405 as IncI plasmids (table III). Plasmid pWG80 appeared to be indistinguishable from pI6187 and, therefore, these results extend the observations of Shalita et al. (1980) that plasmids of this type are found in staphylococci isolated in widely distributed hospitals. Of greater interest were plasmids pWG404 and pWG405. The former plasmid is representative of the pase plasmids carried by MRSA strains predominant at Royal Perth Hospital before 1973 (Townsend et al., 1984c). The latter plasmid was from a MRSA isolated at Royal Perth Hospital in 1982, which has become rare in Australia since MRSA strains carrying resistance to NAB have become prevalent (Grubb et al., 1983; Townsend et al., 1984a).

All the evidence suggests that previously reported MRSA strains characteristically carried an IncI, pase plasmid. Dyke (1969) reported that MRSA strains produced type-A pase and the determinant for this is usually carried on IncI plasmids (Peyru et al., 1969). Furthermore, Dornbusch (1973) reported that the pase plasmid in a MRSA was displaced by an incoming IncI plasmid. Finally, the IncI plasmids pWG404 and pWG405 are phenotypically indistinguishable from pase plasmids previously detected in MRSA strains (Lacey and Grinsted, 1973). These results show clearly that the earlier MRSA strains would not have been able to acquire a NAB-resistance plasmid while still retaining an IncI pase plasmid.

MRSA strains characteristically produce pase. Although the reason for this has not been ascertained it has been suggested that pase is essential for them (Lacey, 1975). 
Both the older MRSA strains and the more recent isolates from Australia produce pase. In the former strains, the determinants are on an IncI plasmid, whereas, in the latter isolates, the determinants are chromosomal. This, together with other genetic studies, suggests that the two types of MRSA are unrelated (Lyon et al., 1982; Grubb et al., 1983; Townsend et al., $1983 b$ and $c$; Lyon et al., 1984; Townsend et al., 1984c). However, Gedney and Lacey (1982) have suggested that the Australian MRSA isolates have the same clonal origin as other MRSA strains. If this is the case, the recent Australian isolates have subsequently undergone a rearrangement of their resistance determinants.

Based on this assumption, an original clonal MRSA carrying an IncI, pase plasmid has several alternatives if it is to retain the determinants of this plasmid and is under selection pressure to acquire an IncI, NAB-resistance plasmid: recombination between the two plasmids, integration of one of the plasmids into the chromosome or transposition of plasmid-borne determinants to another replicon.

The first of these alternatives, recombination between plasmids, has been shown to occur in laboratory conditions (see table IV). Colonies carrying recombinant plasmids were detected by their larger size on double-selection plates. This is in keeping with the results of other studies on recombinant plasmids generated from incompatible plasmids (Novick, 1969; Novick and Brodsky, 1972). Based on their phenotype, Inc group and mol. wt, the NAB-resistance plasmids, pWG278, pWG202 and pWG200, transferred from Singapore MRSA strains, appear to have resulted from recombination between a pase, heavy-metal-resistance plasmid and a NAB-resistance plasmid. Another example of a naturally occurring recombinant plasmid is pWG50, isolated from MRSA strain WG526 (Townsend et al., 1983b). This is also an IncI plasmid (Table III) and has been previously characterised as a recombinant plasmid based on phenotype and restriction-enzyme analysis (Townsend et al., 1984a). A more detailed study is necessary before one can conjecture about the selective pressures that have influenced the emergence of these plasmids.

The second alternative, namely insertion of a plasmid into the chromosome, provides a possible explanation for Australian MRSA strains, because recombination between the pase plasmids and the NAB-resistance plasmids does not appear to have been the major event in these strains. Wyman and Novick (1974) have reported the complete integration of an IncI plasmid, accompanied by loss of incompatibility, subsequent to double selection for two IncI plasmids. Other integrations of this type frequently involved inactivation of the Asa-resistance determinant (Schwesinger and Novick, 1975). Australian strains of MRSA are also Asa sensitive and have chromosomal pase and heavy-metal-resistance, which is in keeping with the integration of a pase plasmid. Novick (1979) has reported that an integrated, IncI, pase plasmid still expressed the Inc genes. In order for the NAB-resistance plasmids to be maintained in the Australian MRSA strains, the Inc genes of the putative, integrated, pase plasmid would have to be suppressed or deleted.

The third alternative, recombination via transposition events, provides another route for the evolution of Australian MRSA strains. The pase determinants in an Australian MRSA strain have been shown to be transposable (Tn 3852; Kigbo et al., in press) and the $\mathrm{Hg}$-resistance operon of IncI plasmids is potentially a transposable element (Shalita et al., 1980). Thus, the acquisition of a NAB-resistance plasmid may have been accompanied by transposition of the pase and heavy-metal-resistance 
determinants into the chromosome. In laboratory conditions, when plasmids pWG80 and pWG53 were selected on $\mathrm{Gm}$ and $\mathrm{Cd}$, the most common event was the insertion of the Gm-resistance determinant into the chromosome. This was ascertained from the stability of the Gm-resistance determinant and the fact that the single plasmid retained (e.g., WG1357, table IV) was identical in mol. wt to plasmid pWG80. These results are not surprising in view of the high transposition frequencies of the Gm-resistance transposon, Tn3851, which is believed to be located on plasmid pWG53 (Townsend et $a l ., 1984 b$ ). Furthermore, these results emphasise the importance of selective pressure in determining the type of recombination event likely to be detected.

These results and conjectures provide some insight into the possible molecular events which must have occurred if the Australian MRSA strains evolved from the original MRSA clone. Furthermore, incompatibility between plasmids has been used as a means of classifying plasmids into related groups (Iordanescu et al., 1978). The above results suggest that incompatibility between plasmids may play an important role in shaping the molecular evolution of a particular strain.

An alternative solution is that Australian MRSA strains have arisen from a different series of events which coincidentally provided a favourable genetic background for the acquisition of the NAB-resistance plasmids. The fact that the Australian strains also differ from other MRSA strains in having, for example, chromosomal Tc resistance and low-level, chromosomal $\mathrm{Sm}$ resistance, tends to support this hypothesis. However, there may have been other pressures, not yet elucidated, that resulted in these changes.

Regardless of whether the Australian MRSA strains have or have not evolved from the postulated 'single clone', a study of the properties conferred by this new family of IncI, NAB-resistance plasmids may lead to an understanding of why these strains have spread so successfully in Australian hospitals.

The following are gratefully acknowledged: Drs J. W. Pearman and D. I. Annear, Royal Perth Hospital, and Dr Tay Leng Singapore for supplying strains; Schering Corporation for the gentamicin; Abbott, Australia for the erythromycin; and May and Baker, Australia for the propamidine isethionate. This work was funded by the Royal Perth Hospital Research Foundation and by grants to W.B.G. from TVW Telethon and from the National Health and Medical Research Council.

\section{REFERENCES}

Annear D I, Grubb W B 1972 Unstable resistance to kanamycin, lincomycin and penicillin in a methicillin resistant culture of Staphylococcus aureus. Pathology 4:247-252.

Dornbusch K 1973 Compatibility tests between genetic linkage groups in a strain of Staphylococcus aureus. Journal of General Microbiology 76:13-19.

Duggleby R G, Kinns H, Rood J I 1981 A computer program for determining the size of DNA restriction fragments. Analytical Biochemistry 110:49-55.

Dyke K G H 1969 Penicillinase production and intrinsic resistance to penicillins in methicillin-resistant cultures of Staphylococcus aureus. Journal of Medical Microbiology 2:261-278.

Emslie K R, Townsend D E, Grubb W B 1985 A resistance determinant to nucleic acid-binding compounds in methicillin-resistant Staphylococcus aureus. Journal of Medical Micriobiology 20:In press.

Emslie K R, Townsend D E, Grubb W B Two distinct resistance determinants to nucleic acid-binding compounds in Staphylococcus aureus? FEMS Microbiology Letters In press.

Gedney J, Lacey R W 1982 Properties of methicillin-resistant staphylococci now endemic in Australia. The Medical Journal of Australia 1:448-450. 
Grubb W B, O'Reilly R J 1971 Joint transduction of separate extrachromosomal drug resistance determinants in Staphylococcus aureus E169. Biochemical and Biophysical Research Communications 42:377-383.

Grubb W B, Townsend D E, Greed L C, Ashdown N, Momoh M 1983 Characteristics of methicillin-resistant Staphylococcus aureus endemic in Australian hospitals. In: Spitzy KH, Karrer K (eds) Proceedings of 13th International Congress of Chemotherapy, Vienna, Verlag H. Egermann Pt 83:23-26.

Iordanescu S, Surdeanu M 1980 New incompatiblity groups for Staphylococcus aureus plasmids. Plasmid 4:256-260.

Iordanescu S, Surdeanu M, Della Latta P, Novick R 1978 Incompatibility and molecular relationships between small staphylococcal plasmids carrying the same resistance marker. Plasmid 1:468-479.

Kigbo E P, Townsend D E, Ashdown N, Grubb W B Transposition of penicillinase determinants in methicillin-resistant staphylococcus aureus. FEMS Microbiology Letters In press.

Lacey R W 1972 Genetic control in methicillin-resistant strains of Staphylococcus aureus. Journal of Medical Microbiology 5:497-508.

Lacey R W 1975 Antibiotic resistance plasmids of Staphylococcus aureus and their clinical importance. Bacteriological Reviews 39:1-32.

Lacey R W, Grinsted J 1973 Genetic analysis of methicillin-resistant strains of Staphylococcus aureus; evidence for their evolution from a single clone. Journal of Medical Microbiology 6:511-526.

Lyon B R, Iuorio J L, May J W, Skurray R A 1984 Molecular epidemiology of multiresistant Staphylococcus aureus in Australian hospitals. Journal of Medical Microbiology 17:79-89.

Lyon B R, May J W, Marshall J H, Skurray R A 1982 Plasmid-mediated antibiotic resistance in methicillin-resistant Staphylococcus aureus. The Medical Journal of Australia 1:468-469.

Lyon B R, May J W, Skurray R A 1983 Analysis of plasmids in nosocomial strains of multiple-antibiotic-resistant Staphylococcus aureus. Antimicrobial Agents and Chemotherapy 23:817-826.

McDonald P J 1982 Methicillin-resistant staphylococci. A sign of the times? The Medical Journal of Australia 1:445-446.

Novick R P, Murphy E, Gryczan T J, Baron E, Edelman I 1979 Penicillinase plasmids of Staphylococcus aureus: restriction-deletion maps. Plasmid 2:109-129.

Novick R P 1969 Extrachromosomal inheritance in bacteria. Bacteriological Reviews 33:210-263.

Novick R P 1979 The molecular basis of the plasmid state. In: Hertman, I (ed) Extrachromosomal inheritance in bacteria; Contributions to Microbiology and Immunology, no. 6. Karger, Basel, Switzerland, pp 1-15.

Novick R P, Bouanchaud D 1971 Extrachromosomal nature of drug resistance in Staphylococcus aureus. Annals of the New York Academy of Science 182:279-294.

Novick R P, Brodsky R 1972 Studies on plasmid replication. I. Plasmid incompatibility and establishment in Staphylococcus aureus. Journal of Molecular Biology 68:285-302.

Novick R P, Hoppensteadt F C 1978 On plasmid incompatibility. Plasmid 1:421-434.

Novick R P, Murphy E, Gryczan T J, Baron E, Edelman I 1979 Penicillinase plasmids of Staphylococcus aureus: restriction-depletion maps. Plasmid 2:109-129.

Novick R P, Richmond M H 1965 Nature and interactions of the genetic elements governing penicillinase synthesis in Staphylococcus aureus. Journal of Bacteriology 90:467-480.

Pavillard R et al. 1982 Epidemic of hospital-acquired infection due to methicillin-resistant Staphylococcus aureus in Victorian hospitals. The Medical Journal of Australia 1:451-454.

Peyru G, Wexler L F, Novick R P 1969 Naturally occurring penicillinase plasmids in Staphylococcus aureus. Journal of Bacteriology 98:215-221.

Ruby C, Novick R P 1975 Plasmid interactions in Staphylococcus aureus: Nonadditivity of compatible plasmid DNA pools. Proceedings of the National Academy of Science, USA 72:5031-5035.

Schwesinger M D, Novick R P 1975 Prophage-dependent plasmid integration in Staphylococcus aureus. Journal of Bacteriology 123:724-738. 
Shalita Z, Murphy E, Novick R P 1980 Penicillinase plasmids of Staphylococcus aureus: structural and evolutionary relationships. Plasmid 3:291-311.

Townsend D E, Ashdown N, Greed L C, Grubb W B 1984a Analysis of plasmids mediating gentamicin resistance in methicillin-resistant Staphylococcus aureus. Journal of Antimicrobial Chemotherapy 13:347-352.

Townsend D E, Ashdown N, Greed L C, Grubb W B 1984b Transposition of gentamicin resistance to staphylococcal plasmids encoding resistance to cationic agents. Journal of Antimicrobial Chemotherapy 14:115-124.

Townsend D E, Greed L C, Ashdown N, Grubb W B 1983a Plasmid-mediated resistance to quaternary ammonium compounds in methicillin-resistant Staphylococcus aureus. The Medical Journal of Australia 2:310.

Townsend D E, Grubb W B, Ashdown N $1983 b$ Gentamicin resistance in methicillin-resistant Staphylococcus aureus. Pathology 15:169-174.

Townsend D E, Grubb W B, Ashdown N 1983c Genetics of drug resistance in methicillin-resistant Staphylococcus aureus from Australian hospitals. Journal of Hospital Infection 4:331-337.

Townsend D E, Grubb W B, Ashdown N, Annear D I, Pearman J W 1984c Genetic analysis of methicillin-resistant Staphylococcus aureus from a Western Australian hospital. Journal of Hospital Infection 5:417-424.

Wyman L, Novick R P 1974 Studies on plasmid replication. IV. Complementation of replication-defective mutants by an incompatibility-deficient plasmid. Molecular and General Genetics 135:149-161. 